\title{
Assessing the level of matrix metal proteinases 1,8,9, their tissue inhibitor, type I, in cases of odontogenic phlegmons
}

\author{
Markelova $\mathrm{EV}^{1}$, Romanchuk $\mathrm{AL}^{1}$, Prosekova $\mathrm{EV}^{2}$, Krasnikov $\mathrm{VE}^{1}$, Beniova $\mathrm{SN}^{3}$ \\ Hominal Physiology and Physiopathology Department, State budget educational institution "Pacific State Medical University”, \\ Healthcare Ministry of the Russian Federation, Vladivostok, Russia. editor3@academicpapers.org
}

\section{ABSTRACT}

The article considers the measured values of the level of MMP-1, MMP-8 and MMP-9, and of their tissue inhibitor Type I (TIMP-1) in the blood serum and mixed saliva samples of 78 patients (31 women - 36.2 \%, 47 men $-63.8 \%$ ) suffering from odontogenic phlegmons in the oral and maxillofacial region. The study indicators were assessed through the enzyme-linked immunosorbent assay using diagnostic sets R\&D Diagnostics Inc. (USA). An uncontrolled hyperactivation of metal proteinases as one of the components of the systemic inflammatory response in case of phlegmon-related complications in the oral and maxillofacial region, as well as development of the sepsis syndrome were studied and it was determined that it results in distortion of the processes of reparative hystogeny and compel us to employ new approaches to the treatment of this type of patients (Tab. 2, Fig. 1, Ref. 13). Text in PDF www.elis.sk.

KEY WORDS: metal proteinases, tissue inhibitor of metal proteinases, odontogenic phlegmons.

\section{Expert commentary}

Matrix metal proteinases cause damage of extracellular matrix, which leads to inflammatory processes extension. The study of MMPs and their tissue inhibitors in suppurative-septic diseases is fundamental and of practical importance with regard to search of means for goal-oriented treatment of extracellular matrix damage and remodelling.

Further studies are presumed to be aimed at search of means affecting, directly or indirectly, the MMP level and/or their tissue inhibitors. From this point of view, it is possible to use anti-cytokine preparations preventing from activation of TNF-alpha, IL-1 $\beta$, IL-6, metal proteinases and antibiotics (doxycycline) inducing TIMP production.

\section{Key issues}

1. The assessment of diagnostic and predictive importance of researches of MMP-1, MMP-8, MMP-9 and their type I tissue inhibitor in maxillofacial phlegmons.

\footnotetext{
${ }^{1}$ Hominal Physiology and Physiopathology Department, State budget educational institution "Pacific State Medical University", Healthcare Ministry of the Russian Federation, Vladivostok, Russia, ${ }^{2}$ Department of Clinical Pathology and General and Clinical Immunology, State budget educational institution "Pacific State Medical University", Healthcare Ministry of the Russian Federation, Vladivostok, Russia, and ${ }^{3}$ Clinical Medicine Department, Federal State Autonomous Educational Institution of Higher Professional Education "Far Eastern Federal University" of Ministry of Education and Science of the Russian Federation, Vladivostok, Russia

Address for correspondence: E.V. Markelova, MD, Hominal Physiology and Physiopathology Department, State budget educational institution "Pacific State Medical University", Healthcare Ministry of the Russian Federation, 4 Ostryakova prospekt, Vladivostok, Russia, 690002.

Phone/Fax: +784232450700
}

2. Seek for new markers of patient status severity assessment in suppurative-septic diseases in maxillofacial region.

3. Theoretical justification of new pathogenic therapy strategies in phlegmons in maxillofacial region.

\section{Introduction}

Odontogenic dental periostitis is the most frequent reason for ambulatory care visits to a dental surgeon. In the majority of cases, when the nidus of the infection is timely cured and an adequate antibacterial and symptomatic therapy is administered, the spread of infection can be hindered. However, in some cases, despite the treatment being provided, the onset of inflammatory process takes place and complications such asodontogenic phlegmons, mediastinitis and sepsis. Phlegmons are the most widespread form of pyoinflammatory process in the oral and maxillofacial region do develop. This is the reason why the problem of diagnosis and treatment of patients with suppurative dentofacial inflammations remains as urgent as ever (1).

Inflammation in this area of human body is characterized by the disturbance of all comprising structures, including the extracellular matrix (ECM). ECM is a complex multi-component molecular structure which ensures the tissue continuity, its specific properties and, at the same time, ECM is capable of interaction with surrounding cells. Remodeling of ECM's collagen fibres, release of soluble factors out of it and transformation of many non-matrix substrates is done by matrix metal proteinases (MMP). MMP is a small group of proteolytic ferments whose physiological functions are tissue remodeling, angiogenesis and bone system shaping. Their activity is regulated by cytokines, growth factors and specific tissue inhibitors (TIMP) $(2,3,4)$. 


\section{1-55}

All MMPs are synthesized as zymogenes and secreted in a latent form. Zymogene activation proceeds with the involvement of a range of proteases outside of a cell or on its surface. Ferment activity depends on both gene expression and the presence of activators and inhibitors. The level of genes expression - those which regulate MMP and mRNA stability - changes rapidly in the process of ECM remodeling.

MMPs belong to 'inducible' enzymes, with the only exception of MMP-2 which expression proceeds constitutively (3).

In case of inflammation, there a considerable activation of metal proteinases and their tissue inhibitors takes place, which results in a dynamic change of these mediators in the lesion. The metal proteinases - which destroy the intercellular matrix - play a crucial role in the process of inflammation and tissue regeneration; investigation of the activity of various MMPs shall help us to get a better and deeper understanding of the processes of inflammation-related tissue damages in the oral and maxillofacial region.

\section{The aim of the study}

To reveal the pathogenic and diagnostic significance of the change of the level of MMP-1, MMP-8, MMP-9 and their type I tissue inhibitor in maxillofacial phlegmons.

\section{Methods and materials}

There was a research carried out along with examination and treatment of 78 patients ( 31 women $-36.2 \%$, and 47 men -63.8 $\%$ ) aged $38.6 \pm 3.4 \mathrm{y} / \mathrm{o}$, with maxillofacial odontogenic phlegmons; all of them were indoor patients at the Oral and Maxillofacial Surgery Unit, Regional Clinical Hospital No. 2, city of Vladivostok. All the patients were admitted to hospital by emergency hospitalization and were examined and then treated in compliance with the adopted standards of healthcare. Their diagnoses relied on the results of objective examination methods and intraoperative data, in accordance with the ICD-10. The patients were divided into three groups, depending on the extension of the inflammatory process. The first group ( 25 patients $-29.3 \%$ ) included those with only one anatomical region affected, the second group (32 patients $44.8 \%$ ) - those with several anatomical regions affected, the third group (21 patients $-25.9 \%$ ) included people with phlegmonouse cellulitis of the floor of the mouth: Ludwigs angina, septic syndrome and mediastinitis. The reference group comprised of apparently healthy people (20 persons aged 20-50 (34.2 \pm 3.1$) \mathrm{y} / \mathrm{o})$.

The level of MMP-1, MMP-8 and MMP-9 was measured, and of their tissue inhibitor, type I (TIMP-1), in blood serum and in mixed saliva samples, by enzyme-linked immunosorbent assay and using diagnostic sets R\&D Diagnostics Inc. (USA). Statistical processing of the obtained results was carried out using the software package «Statistica-10» (parametric methods). To assess variance between dependent and independent samples, Student's t-test was used. The degree of dependence between various indicators within the study groups was assessed by the Spearman rank correlation test and $\chi^{2}$. The statistical significance level at which zero-hypotheses were rejected, was less than 0.05 .

\section{Results}

MMP-1 - is the first tissue ferment which hydrolyzes the spiral section of collagen (4). The main substrate of collagenases is a spiral fibrillar collagen, types I, II and III, the degradation products of which become a substrate for further breakdown by gellatinases and stromelysins. As this takes place, interstitial collagenase (MMP-1) is synthesized by a number of cells: fibroblasts, chondrocytes, epithelial cells including keratinocytes, macrophages and osteoblasts (5).

The study revealed a statistically significant increase of its level in blood serum and in mixed saliva for odontogenic phlegmons $(\mathrm{p}<0.003)$. At the same time, for men its level was $1.5-2$ times as much as that for women $(\mathrm{p}<0.02)$ (Tab. 1). This confirms empirical data provided in an overview by Rovoga et al (2011) concerning the impact of estrogens upon the output of MMP-1.

The assessment of the level of MMP-1 in biological fluids of the patients, depending on the extension of the process, leads to a conclusion that in blood serum samples of all the patients the level of MMP-1 was high (Tab. 1). Already in the group with only one anatomical region affected, its level was at the average 2 times more than in the reference group, remaining practically at the same level in cases of two and more affected anatomical regions. The largest values of MMP-1 concentration $(\mathrm{p}<0.01)$ were revealed in

Tab. 1. MMP-1,8,9 and TIMP-1 content in the blood serum of patients with dentofacial odontogenic phlegmons.

\begin{tabular}{|c|c|c|c|c|c|c|c|c|}
\hline \multirow{4}{*}{\multicolumn{2}{|c|}{$\begin{array}{c}\text { Content, } \\
\text { assessment of } \\
\text { No proteins in blood } \\
\text { serum } \mathrm{mg} / \mathrm{ml}\end{array}$}} & \multicolumn{7}{|c|}{ Study Groups } \\
\hline & & \multirow{3}{*}{$\begin{array}{l}\text { Reference } \\
\text { Group }\end{array}$} & \multicolumn{6}{|c|}{ Patients with dentofacial odontogenic phlegmons } \\
\hline & & & \multirow{2}{*}{ General Group } & \multirow{2}{*}{ Men } & \multirow{2}{*}{ Women } & \multicolumn{3}{|c|}{ Extension of the Process } \\
\hline & & & & & & 1 & 2 & 3 \\
\hline 1 & MMP-1 & $1.8 \pm 0.10$ & $4.00 \pm 0.28^{* * *}$ & $\begin{array}{c}5.10 \pm 0.38 * * * \\
\mathrm{p}_{4}<0.009\end{array}$ & $3.35 \pm 0.42 * * *$ & $\begin{array}{c}3.57 \pm 0.16^{* * * *} \\
\mathrm{p}_{1-2}>0.05\end{array}$ & $\begin{array}{c}4.02 \pm 0.44 * * * \\
\mathrm{p}_{2 \mathrm{rmm} 3}>0.05\end{array}$ & $\begin{array}{c}4.42 \pm 0.27 * * * \\
\mathrm{p}_{1-3}<0.01\end{array}$ \\
\hline 2 & MMP-8 & $12.61 \pm 0.68$ & $27.71 \pm 2.63 * * *$ & $28.84 \pm 3.11^{* * *}$ & $\begin{array}{c}25.17 \pm 4.81^{* * * *} \\
\mathrm{p}_{4}>0.05\end{array}$ & $\begin{array}{c}26.48 \pm 1.57 * * * \\
\mathrm{p}_{1-2}>0.05\end{array}$ & $\begin{array}{c}22.89 \pm 3.06^{* * * *} \\
\mathrm{p}_{2-3}<0.05\end{array}$ & $\begin{array}{c}32.22 \pm 2.50 * * * \\
\mathrm{p}_{1-3}<0.05 \uparrow\end{array}$ \\
\hline 3 & MMP-9 & $277.49 \pm 24.41$ & $482.36 \pm 21.45^{* * *}$ & $499.72 \pm 30.01 * * *$ & $\begin{array}{c}453.85 \pm 24.30^{* * *} \\
\mathrm{p}_{4}>0.05\end{array}$ & $\begin{array}{c}470.93 \pm 27.31 * * * \\
\mathrm{p}_{1-2}>0.05\end{array}$ & $\begin{array}{c}451.26 \pm 31.35^{* * *} \\
\mathrm{p}_{2-3}>0.05\end{array}$ & $\begin{array}{c}488.91 \pm 25.60^{* *} \\
\mathrm{p}_{1-3}>0.05\end{array}$ \\
\hline 4 & TIMP-1 & $220.30 \pm 5.29$ & $296.73 \pm 10.08^{* * *}$ & $300.05 \pm 13.23 * * *$ & $\begin{array}{c}289.35 \pm 9.82 * * * \\
\mathrm{p}_{4}>0.05\end{array}$ & $\begin{array}{c}306.72 \pm 18.09 * * * \\
\mathrm{p}_{1-2}>0.05\end{array}$ & $\begin{array}{c}274.49 \pm 17.40^{*} \\
\mathrm{p}_{2-3}>0.05\end{array}$ & $\begin{array}{c}302.66 \pm 8.50 * * * \\
\mathrm{p}_{1-3}>0.05\end{array}$ \\
\hline
\end{tabular}


Tab. 2. MMP-1,8,9 and TIMP-1 content in the mixed saliva of patients with dentofacial odontogenic phlegmons.

\begin{tabular}{|c|c|c|c|c|c|c|c|c|}
\hline \multirow{4}{*}{ No } & \multirow{4}{*}{$\begin{array}{c}\text { Content, } \\
\text { assessment of } \\
\text { proteins in blood } \\
\text { serum } \mathrm{mg} / \mathrm{ml}\end{array}$} & \multicolumn{7}{|c|}{ Study Groups } \\
\hline & & \multirow{3}{*}{$\begin{array}{l}\text { Reference } \\
\text { Group }\end{array}$} & \multicolumn{6}{|c|}{ Patients with dentofacial odontogenic phlegmons } \\
\hline & & & \multirow{2}{*}{ General Group } & \multirow{2}{*}{ Men } & \multirow{2}{*}{ Women } & \multicolumn{3}{|c|}{ Extension of the Process } \\
\hline & & & & & & 1 & 2 & 3 \\
\hline 1 & MMP-1 & $0.46 \pm 0.03$ & $1.06 \pm 0.19 * * *$ & $1.13 \pm 0.21 * * *$ & $\begin{array}{c}0.96 \pm 0.13^{* * *} \\
\mathrm{p}_{4}<0.05\end{array}$ & $\begin{array}{c}0.67 \pm 0.16 \\
\mathrm{p}_{1-2}>0.05\end{array}$ & $\begin{array}{c}1.07 \pm 0.12^{* *} \\
\mathrm{p}_{2-3}>0.05\end{array}$ & $\begin{array}{c}1.35 \pm 0.32^{* *} \\
\mathrm{p}_{1-3}<0.05\end{array}$ \\
\hline 2 & MMP-8 & $39.00 \pm 3.50$ & $47.12 \pm 2.45$ & $46.18 \pm 3.68$ & $\begin{array}{c}47.54 \pm 4.26 \\
\mathrm{p}_{4}>0.05\end{array}$ & $\begin{array}{c}42.54 \pm 3.90 \\
\mathrm{p}_{1-2}>0.05\end{array}$ & $\begin{array}{c}48.44 \pm 2.50 * \\
\mathrm{p}_{2-3}>0.05\end{array}$ & $\begin{array}{c}52.20 \pm 2.06^{* *} \\
\mathrm{p}_{1-3}<0.05 \uparrow\end{array}$ \\
\hline 3 & MMP-9 & $1.56 \pm 0.30$ & $2.50 \pm 0.35^{*}$ & $2.80 \pm 0.28 *$ & $\begin{array}{c}2.30 \pm 0.38 \\
\mathrm{p}_{4}>0.05\end{array}$ & $\begin{array}{l}1.97 \pm 0.40 \\
\mathrm{p}_{1-2}>0.05\end{array}$ & $\begin{array}{l}1.84 \pm 0.18 \\
\mathrm{p}_{2-3}<0.01\end{array}$ & $\begin{array}{c}3.77 \pm 0.60^{* *} \\
\mathrm{p}_{1-3}<0.05\end{array}$ \\
\hline 4 & TIMP-1 & $2.40 \pm 0.04$ & $2.55 \pm 0.20$ & $2.66 \pm 0.25$ & $\begin{array}{c}2.25 \pm 0.30 \\
\mathrm{p}_{4}>0.05\end{array}$ & $\begin{array}{c}2.91 \pm 0.34 \\
\mathrm{p}_{1-2}>0.05\end{array}$ & $\begin{array}{c}2.71 \pm 0.22 \\
\mathrm{p}_{2-3}<0.01\end{array}$ & $\begin{array}{c}1.90 \pm 0.15^{* *} \\
\mathrm{p}_{1-3}<0.05 \downarrow\end{array}$ \\
\hline
\end{tabular}

Statistical validity of differences with: reference group $* * * \mathrm{p}<0.001, * * \mathrm{p}<0.01, * \mathrm{p}<0.05, \mathrm{p}_{1,2,3}$ groups by process extension; $\mathrm{p}_{4}$ by sex

Group III. Somewhat different amounts of MMP-1 were detected in saliva: its content in group I was increased only for $27 \%$ of the patients; by and large the revealed data in this group did not differ much from the reference group. At the same time, in groups II and III its concentrations were statistically significantly higher than both, in the reference group and in the one with only one anatomical region affected by inflammation (Tab. 2).

MMP-8 was observed in neutrophils, due to which reason it took the name of neutrophilic collagenase. MMP- 8 accumulates itself in the specific granules which circulate inside neutrophils.

It is active to predominantly type I collagen. MMP- 8 synthesis by macrophages, endothelial and smooth muscle cells is linked to a prolonged effect of proinflammatory cytokines (5). Other sources of MMP-8 are epithelial cells, fibroblasts, monocytes and macrophages (6).

A high concentration of MMP-8 in saliva was detected, including in apparently healthy people. Its quantitative values in saliva were 3 times in excess of its level in blood serum, which is presumably related to the constant activation of its output by the oral microflora. At the same time we should note, that the local level of neutrophil metal proteinase was significantly increased for patients in group II and, especially, Group III (Tab. 2). What concerns the systemic level, MMP-8 values are in excess of the reference values for all studied patients, with the maximum increase observed in severely ill patients in group III, which only confirms a systemic inflammation response - involving neutrophils - that develops in them.

Gelatinase B (MMP-9) belongs to the second sub-family of metal proteinases - type IV collagenase. It splits entactin and collagen of the IV and V types (3). MMP-9 was found in neutrophils and macrophages, as well as in fibroblasts, chondrocytes, T-lymphocytes and endothelial cells upon stimulation by cytokines, phorbol ester, oncogenes, and also in the infected cells (7).

It was established that the MMP-9 level was 100 and more times higher in blood serum, both in the reference group, and among the patients, if compared with its level in mixed saliva (Tabs 1 and 2). The appropriate blood serum values were increased for all patients having maxillofacial phlegmons regardless of the process extension (Tab. 1). When measuring the level of MMP-9 in mixed saliva, we found its increase only for group III patients with an extensive inflammation process, which stood in relation with the development of the sepsis syndrome $(r=0.82$, $\mathrm{p}<0.0023)$.

Metal proteinase activity is regulated under physiological conditions by specific tissue inhibitors - TIMPs which suppress MMP's activity due to forming a complex with them at the ratio of $1: 1$. Removal of TIMPs from this complex results in MPP activation $(3,7)$.

TIMP proteins can inhibit practically any MMP, with different constants, however $(3,8,9,10)$.

Compensatory increase of type I tissue inhibitor of metal proteinases (TIMP-1) in the blood serum samples of the examined patients was revealed. The inhibitor's concentration stood in no relation to sex or process extension (Tab. 1).

Other data was obtained from the assessment of TIMP-1 in the patients' saliva: no significant differences in its local output levels were observed, except for group III patients with a severe extensive process. In this group, TIMP-1's deficit was revealed (Tab. 2).

\section{Discussion}

Pyoinflammatory diseases of the maxillofacial type belongs to some of most severe and extensive pathologies and can cause lifethreatening complications and a lethal outcome. Due to the high speed of their development, the assessment of the process extension is in many cases possible only postoperatively. In relation to this, a better understanding of the disease pathogenesis and discovery of new diagnostic criteria shall remain an ever important problem.

Matrix metal proteinases can affect the key components of the connective tissue matrix, the output of biologically active substances and cell cooperation (11). Metal proteinases do participate in the development and regulation of the inflammatory reaction, by activating antimicrobic proteins-prodefensins, by regulating neutrophil and macrophage migration, vascular permeability and the activity of cytokines and chemokines. Metal proteinases (MMP-1, $-3,-9)$ are instrumental in endothelial cell migration, the latter being angiogenesis stimulators $(12,13)$. But after the split of a part of the matrix to its components (hyaluronic acid, elastin, collagen), they intensify chemotaxis and activation of neutrophils, macrophages and other cells to form the reactive oxygen intermediates and proteases which maintain the pathologic cascade and repeatedly affect the extracellular matrix. 


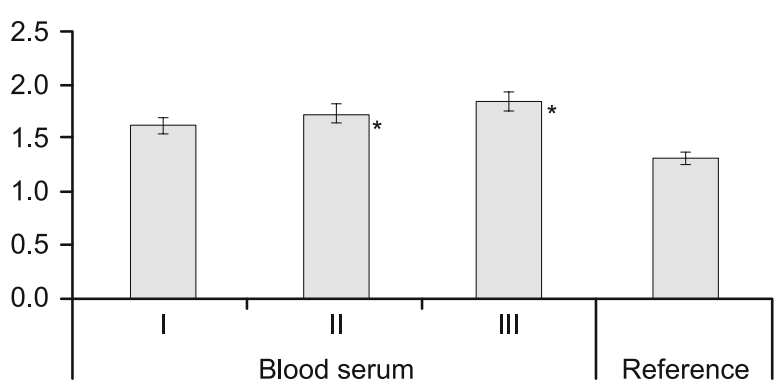

a

$\square$ MMP-1+MMP-8+MMP-9/TIMP-1

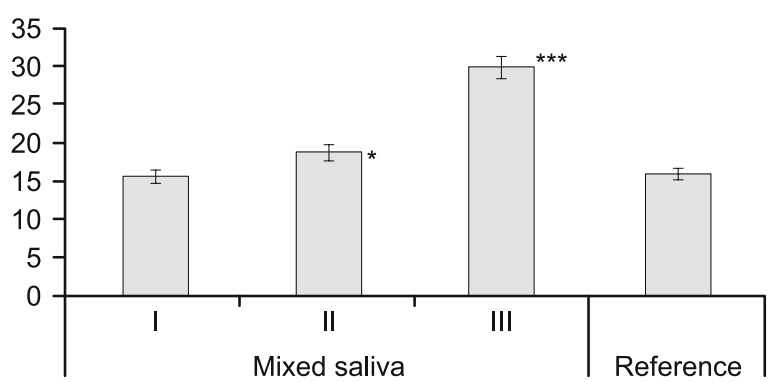

(b)

$\square$ MMP-1+MMP-8+MMP-9/TIMP-1

Fig. 1. The MMP-1+MMP-8+MMP-9/TIMP-1 ratio in blood serum (a) and mixed saliva (b), patients with maxillofacial phlegmons.

With due regard to the protective and adaptive potential of metal proteinases, we studied the levels of MMP-1, MMP-8, MMP-9 and their type I tissue inhibitors both at the system level (in blood serum) and locally (in mixed saliva).

In blood serum samples, an average two-fold increase of the level of the studied metal proteinases already in group I patients with phlegmons in one anatomical region was found; simultaneously the concentration of TIMP-1 did rise 1.4-1.6 times, which caused a moderate increase of the ratio of metal proteinases (Fig. 1a) to its inhibitor, the levels of the latter not going beyond the range of reference values (Tab. 1). This testifies to the fact that there was a balance in their system which is adequate to the inflammatory process.

For patients from group II with inflammatory processes extending over two and more anatomical regions, the quantitative values of MMP-1, MMP-8 and MMP-9 were high but statistically not significantly at variance with group I results.

However, two factors attract our attention: first, a more pronounced scatter of individual indicators and, second, an increase of the value of the coefficient MMP-1+MMP-8+MMP-9/TIMP-1 as compared to the reference group $(\mathrm{p}<0.005)$. This can be accounted for both by differences within the group pertaining to the extension of the process and by the heterogeneity of cytokine regulation as presented, among others, in our works. But the increase of the MMP/TIMP coefficient speaks of some general patterns indicative of a relative exhaustion of the regulatory effect of tissue inhibitors, and of a threat that a systemic inflammation can take place.

In the group of patients with complications, such as developing contact mediastinitis, sepsis, Ludwigs angina, blood serum samples showed a statistically significant build-up of MMP-1, MMP-8, which led to an increase of the regulatory coefficient. This reflects the predominance of a systemic output of metal proteinases involving large amounts of immune competent cells along with endotheliocytes.

Assessment of the local levels of the studied metal proteinases allowed us to reveal some general patterns characterized by a considerable increase of MMP-1, MMP-8 and MMP-9 among the group III patients. At the same time, these patients demonstrated a TIMP deficit and, accordingly, a drastic rise of the MMP/TIMP coefficient reflecting the uncontrolled metal proteinase activation. It was established that the increase of MMP-1+MMP-8+MMP-9/ TIMP-1 of more than 25 involves life-threatening complications for patients with maxillofacial phlegmons $\left(\chi^{2}=6.2\right.$, with two degrees of freedom, $\mathrm{p}<0.01$ ).

It is important to note here that, on the whole, group I patients' saliva did not reveal any statistically significant concentration increase of the studied metal proteinases and their tissue inhibitor, at the moment of their admission to hospital. Yet, even among those patients, nearly for one-third of them (27\%) an increase of the level of these acute-phase proteins was detected, which indicates again the heterogenic nature of the disease progression and pre-determines further study of pathogenic profiles, in order to develop targeted therapy and prevent the development of complications.

In group II, with the inflammation process extending to two and more anatomical regions, a considerable increase of the concentration of MMP-1 and MMP-8 in saliva was detected, which speaks of their de novo production. A low level of MMP-9 in saliva samples, if compared to its values in blood serum, also confirms, in our view, rather the fact of its production de novo then of a better hematosalivary permeability.

Thus, the study results testify to the important role of imbalances in the metal proteinase system for pyoinflammatory diseases of the oral and maxillofacial region.

At the same time, no system imbalances were found in patients having phlegmons in just one anatomical region. When the process extends over two and more anatomical regions, the production of MP-1 and MMP- 8 by immune competent cells in the oral cavity rises, while the output of TIMP does not, which leads to the distortion of their ratio.

In case of phlegmon-related complications in the oral and maxillofacial region, development of the sepsis syndrome, we revealed an uncontrolled hyperactivation of metal proteinases as one of the components of the systemic inflammatory response, which distorts the processes of reparative hystogeny and compels us to employ new approaches to the treatment of this type of patients. 


\section{References}

1. Bashilov LI, Chuvnyakin VI, Tsarev VN et al. Osobennosti bakterial'noy diagnostiki pri hirurgicheskom lechenii odontogennyh flegmonah. (Bacterial Diagnostics for Operative Therapy of Odontogenic Phlegmons). Russ Stomatol 2011; 6: 3-7.

2. Poteryaeva ON. Matriksnye metalloproteinazy: stroenie, regulyaciya, rol v razvitii patologicheskih sostoyaniy (Matrix Metal Proteinases: Structure. Regulation. Role in Pathogeny). Med Educ Siberia 2010; 5: 52-58.

3. Lesnichenko IF, Gritsaev CV, Kapustin SI. Matriksnye metalloproteinazy: harakteristika, rol v leykozogeneze i prognosticheskoe znachenie. (Matrix Metal Proteinases: Properties. Role in Leukocytogenesis. Prognostic Value). Oncol Issues 2011; 57 (3): 286-294.

4. Rogova LN, Shesternina NV, Zamechnik TV et al. Matriksnye metalloproteinazy, ih rol'v fiziologicheskih i patologicheskih processah (obzor). (Matrix Metal Proteinases and their Role in Physiological and Pathogenic Processes (Overview)). New Med Technol Bull 2011; 18 (2): 86-89.

5. Yarmolinskaya MI, Molotkov AS, Denisova VM. Matriksnye metalloproteinazy i ingibitory: klassifikaciya, mehanizm deystvie. (Matrix Metal Proteinases and Inhibitors: Classification. Mechanisms of Action). J Obstet Gynaecol 2012; 61 (1): 113.

6. Kiili M et al. Collagenase-2 (MMP-8) and collagenase-3 (MMP-13) in adult periodontitis: molecular forms and levels in gingival crevicular fluid and immunolocalisation in gingival tissue. J Clin Periodontol 2002; 29: 224-232.

7. Nazarov PG. Reaktanty ostroy fazy vospaleniya (Reactants of the Acute Phase of Inflammation). Saint Petersburg: Nauka, 2001.
8. Brew K, Nagase H. The tissue inhibitors of metalloproteinases (TIMPs): An ancient family with structural and functional diversity. NIH Public Access Author Manuscript. 2011.

9. Aksyonenko MB, Ruksha TG. Ocenka vzaimosvyazi ingibirovaniya matriksnoy metalloproteinazy-9 i soderzhaniya kollagenovyh volokon v razlichnyh organah. (Assessing the Relationship betweent Matrix Proteinase-9 Inhibition and the Content of Collagen Fibres in Different Body Organs). Siber Med J 2013; 2: 56-58.

10. Tseymakh IY, Korenovskiy YV, Kostyutchenko GI et al. Rol proteinazno-ingibitornogo disbalansa $\mathrm{v}$ patogeneze sistemnogo vospaleniya i aktivacii sosudisto-gemostaticheskih reakciy u bolnyh s obostreniem hronicheskoy obstruktivnoy bolezni legkih (The Role of Proteinase-Inhibitor Disbalance in the Pathogeny of a Sistemic Inflammation and Activation of Vascular Haemostatic Responses in Patients Having Chronic Obstructive Lung Disease in the Acute Phase) Siber J Med 2013; 28 (1): 54-60.

11. Lee EJ, Moon PG, Baek MC, Kim HS. Comparison of the Effects of Matrix Metalloproteinase Inhibitors on TNF-a Release from Activated Microglia and TNF-a Converting Enzyme Activity. Biomol Ther 2014; 5: 414-419.

12. Rundhaug JE. Matrix metalloproteinases and angiogenesis. J Cell Mol 2005; 9: 267-285.

13. Hotko AA. Rol' matriksnyh metalloproteinaz v razvitii psoriaza i associirovannoy s nim komorbidnosti (The Role of Matrix Metal Proteinases in the Development of Psoriasis and Associated Comorbidity). Saratov J Med Sci 2013; 9 (3): 582-584.

Received November 1, 2016. Accepted December 2, 2016. 